\title{
Pengaruh Model Pembelajaran Problem Based Instruction Berbasis Collaboration, Communication, Creativity and Critical Thinking Terhadap Hasil Belajar Rangkaian Elektonika
}

\author{
Ayu Alam Pertiwi ${ }^{1,2 *}$ dan Fahmi Rizal ${ }^{2}$ \\ ${ }^{1}$ SMK Negeri 3 Lubuk Linggau Sumatera Selatan \\ ${ }^{1,2}$ Program Studi Teknologi dan Kejuruan, Fakultas Teknik, Universitas Negeri padang \\ *Corresponding author, e-mail: ayualampertiwi@gmail.com
}

\begin{abstract}
Abstrak-Pembelajaran Problem Based Instruction (PBI) berbasis keterampilan 4C (Collaboration, Communication, Creativity and Critical Thinking) merupakan pembelajaran yang berpusat pada siswa sehingga dapat melakukan kegiatan pemecahan masalah dan membuat siswa berpikir lebih kritis, mempresentasikan ide kreatif dan berkomunikasi dengan pelajaran secara lebih luas.Model pembelajaran merupakan pedoman perencanaan dalam menentukan perangkat pelajaran dalam kelas.Pembelajaran pada siswa masih berpusat pada guru atau konvensional sehingga kurang memberikan kesempatan kepada siswa untuk mengungkapkan ide sebagai olah pikir siswa secara komunikasi, kolaborasi, kreatif dan berfikir keritis.Penelitian ini bertujuan untuk mengetahui pengaruh model pembelajaran PBI berbasis Keterampilan 4C terhadap hasil belajar rangkaian elektronika. Model pembelajaran PBI berbasis keterampilan 4C menggunakan jenis penelitian eksperimen yang bersifat quasy eksperimen. Dalam penelitian ini pengaruh adanya perlakuan (treatment) di analisis dengan uji beda yaitu kelompok mendapatkan perlakuan beda yaitu kelompok eksperimen model pembelajaran PBI berbasis keterampilan 4C dan kelompok kontrol dengan pembelajaran Konvensional (two group). Dari hasil penelitian menunjukkan peningkatan nilai rata-rata hasil belajar kelas eksperimen lebih tinggi dibandingkan peningkatan nilai rata-rata kelas kontrol dapat disimpulkan bahwa hasil belajar siswa yang menggunakan model pembelajaran problem based instruction berbasis 4C lebih baik dibandingkan siswa yang menggunakan pembelajaran konvensional.
\end{abstract}

Kata Kunci : Problem Based Instruction, keterampilan 4C, Hasil Belajar.

\begin{abstract}
C (Collaboration, Communication, Creativity and Critical Thinking) skill-based Problem Based Instruction (PBI) is student-centered learning so that it can do problem solving activities and make students think more critically, present creative ideas and communicate with the lesson more broadly. The learning model is a planning guide in determining the set of lessons in the classroom. Learning on students is still centered on the teacher or conventional so it does not provide opportunities for students to express ideas as if students think in communication, collaboration, creative and critical thinking. This study aims to determine the effect of the $4 C$ Skillbased Problem Based Instruction learning model on electronic learning outcomes. The $4 C$ skillbased PBI learning model uses a quasy type of experimental research. In this study the effect of the treatment (treatment) was analyzed by different tests, namely the group received different treatment, namely the experimental group PBI learning based on $4 C$ skills and the control group with conventional learning (two groups). From the results of the study showed an increase in the average value of learning outcomes of the experimental class was higher than the increase in the average value of the control class. It can be concluded that the learning outcomes of students who use the 4C-based problem based instruction learning model are better than students who use conventional learning.
\end{abstract}

Keywords : Problem Based Instruction, 4C Skills, Laerning Outcomes. 


\section{Pendahuluan}

Era R.I 4.0 telah membawa semua perubahan dalam aspek kehidupan, mengubah cara hidup, mengaitkan manusia dengan mesin dan mengaitkan manusia dengan manusia [1], mulai dari perubahan IT, komunikasi seluler dan $e$ commerce, media sosial, komunikasi via internet. Perubahan dasar tersebut yaitu big data, Internet Of Things (IOT), Cyber Phisical System, Collaboration System, Cloud Computing, Intelligent Robots [2] terbentuknya suatu pengaruh industri, pemerintahan dan masyarakat yang baik salah satu upaya untuk menciptakan teknologi yang unggul yang memungkinkan terciptanya produk baru, model bisnis dan layanan yang bermanfaat bagi dunia industri [3].

Pada pembelajaran abad 21 selain memiliki tanggung jawab mengembangkan karakter dan literasi, juga bertanggung jawab bagaimana mengembangkan Keterampilan belajar 4C, yaitu; Collaboration, Communication, Creativity and Critical Thinking [4]. Communication adalah pembelajaran yang dilakukan atara pelajar dan pengajar, pengajar dan pelajar, dan pelajar ke pelajar. Colloboration adalah pembelajaran secara berkelompok bersifat demokrasi yang diciptakan antar siswa supaya siswa bisa bertanggung jawab dengan tugas yang didapatkan. Critical thinking merupakan pembelajaran bersifat kritis dalam meyelesaikan permasalahsehari-hari. Creativity adalah pembelajaran yang bersifat kreatif dimana siswa mampu menciptkan inovasi terbaru tanpa harus diintimidasi oleh guru [5].

Pada kompetensi abad 21 memiliki Indikator pembelajaran yang diangkat diantaranya: komunikasi efektif (effective communication), pembelajaran inventif (inventive thinking), era literasi digital (digital age literacy), dan produktivitas tinggi (high productivity) [6]. Pembelajaran abad 21 pada mata pelajaran rangkaian elektronika memiliki dampak yang baik dalam dunia industri salah satunya IoT (Internet of Tings) dimana konsep IoT ini memiliki empat poin yaitu things, connectivity, data dan analytic yang merupakan bagian dari eletronika yang dapat dikembangkan di industri 4.0. Dimana sensor merupakan subjek dari things, connectivity jaringan seperti wifi dan bloetooth, data gabungan dari things dan connectivity serta analytic merupakan outputnya. Keterampilan belajar 4C dianggap dapat memperkuat intellectual capital, dan social capital dan modal untuk industri bagi peserta didik. Keterampilan untuk Abad 21, mengidentifikasi bahwa kompetensi dibutuhkan di abad ke-21 "The 4C's" - komunikasi, kolaborasi, pemikiran kritis, dan kreativitas. Kompetensi ini penting untuk peserta didik dalam bidang pembelajaran dengan materi saat ini yaitu abad ke-21. Ada empat cara menilai dan penbelajaran pada keterampilan abad 21 (ATC21S) yaitu bagaimana cara siswa berfikir, bagaimana cara siswa berkerja, alat apa saja yang digunakan untuk berkerja, dan bagaimana cara bertahan untuk hidup [7]. Dalam berpikir ada beberapa cara meliputi tindakan pengambilan suatu keputusan, aktif dalam berkreativitas, mampu berinovasi, dan dapat berpikir kritis.. Cara kerja meliputi keterampilan komunikasi, kolaborasi, dan kerja sama dalam tim. Berikut kerangka untuk pembelajaran abad 21.

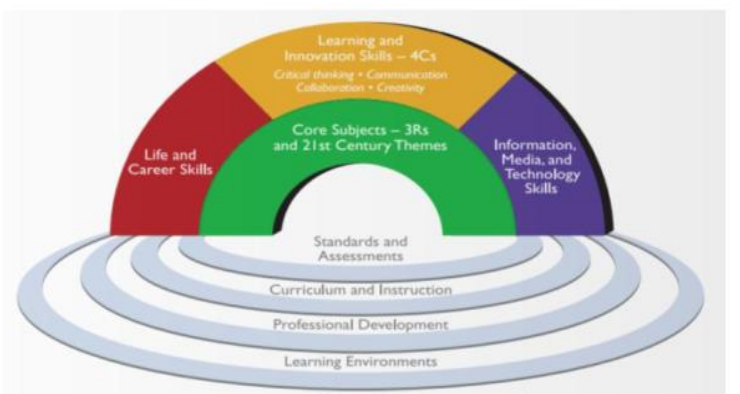

Gambar 1. Framework For $21^{\text {st }}$ Century Learning

Kerangka pembelajaran abad 21 terdiri dari komunikasi, kolaborasi, kritikal tingking dan kreativitas. Kompetensi tersebut merupakan strategi pembelajaran paling populer pada abad 21 dan kopetensi tersebut merupakan kompetensi yang paling penting di abad 21. Berikut empat kompetensi keterampilan abad 21

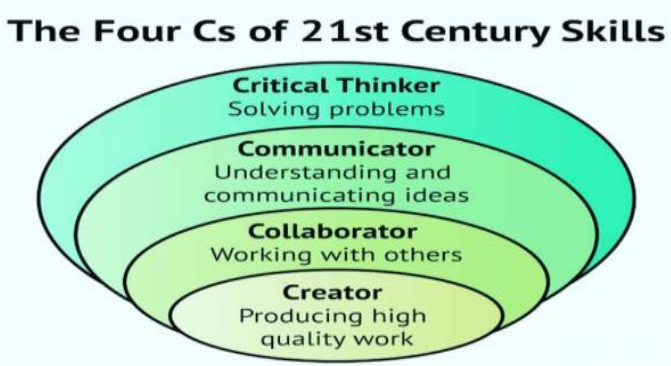

Gambar 2. The Four C's of Century Skills

Kurikulum 2013 atau kita kenal K13 merupakan pendidikan yang berdasarkan standar, sedangkan teori berbasis kompetensi. [8] Pendidikan merupakan kegiatan yang ditekankan pada aspek mental dan rasional yang bernilai instrinsik dan memiliki martabat yang 
mulia.Pendidikan ini mengunakan standar nasional yang berkualitas minimum dimana standar minimum ini sesuai dengan warga negara yang isinya terdiri dari beberapa standar konten yaitu konten proses, lulusan, guru serta staf kependidikan, fasilitas serta infrastruktur, manajemen, biaya, dan penilaian dalam pendidikan. Kurikulum 2013 mampu mendorong peserta didik lebih inovatif serta memiliki sosial yang tinggi. Untuk menghasilkan peserta didik yang memiliki kemampuan tinggi maka salah satu caranya yaitu memvariasikan model pembelajaran. Dimana model pembelajaran yang diterapkan masih banyak menerapkan model konvensional.

Rendahnya hasil belajar rangkaian elektronika di SMK Negeri 3 Lubuklinggau disebabkan oleh faktor diantaranya adalah sebagian besar siswa belum mengetahui prinsip kerja dari komponen elektronika, metode pembelajaran yang disampaiakan oleh guru disadari kurang interaktif dan cenderung bersifat konvensional, serta sistem evaluasi yang belum sesuai standar, dan pendekatan guru kepada siswa juga mempengaruhi rendahnya hasil belajar rangkaian elektronika.

Berdasarkan pengamatantersebut penulis perlu melakukan perubahan pembelajaran menggunakan model yang digunakan oleh guru untuk kegiatan pembelajar yang dapat menghasilkan siswa yang lebih baik di kegiatan belajar. Dalam persoalan tersebut maka salah satunya solusinya adalah diterapkannya model suatu pembelajaran aktif agar siswa dapat meningkatkan keterampilan belajaran, kreatif dan fokus dalam belajar. Hal tersebut dapat terpengaruhnya hasil dari belajar siswa di abad 21. Model pembelajaran Problem Based Instruction (PBI) berbasis keterampilan belajar 4C abad 21 merupakan model yang dianggap sesuai untuk mengatasi persoalan tersebut.

Model pembelajaran adalah perencanaan untuk pedoman perencanaan menentukan perangkat pelajaran didalam kelas. Sagala [9] model merupakan istilah pedoman untuk memahami suatu kerangka konseptual dalam kegiatan pembelajaran. [10] menyatakan bahwa model pembelajaran yang bervariasi membuat siswa senang tiasa memperhatikan guru, termotivasi dan bersunguh-sungguh dalam mengikutipelajaran. Dalam suatu pembelajaran siswa harus mampu belajar karena belajar merupakan proses untuk menghasilkanperubahan dalam berbagai aspek hingga dapatdiukur nilainya yang berfungsi untuk mengetahuisejauh mana suatu program dapat diterapkan [11].

Keberhasilan pembelajaran tentunya didukung oleh model pembelajaran yang bervariasi. [12]Model konseptual merupakan pedoman perencanaan pembelajaran yang tersusun sistematis sebagai pengalaman belajar. Model pembelajaran perpedoman pada pendekatan dari tujuan,lingkungan,tahapan, kegiatan dan pengelolaan. Model pembelajaran merupakan kerangka konseptual yang harus direncanakan secara sistematis sebagai pedoman untuk melakuan pembelajaran dikelas [13].

Suatu model pembelajaran terdiri dari empat ciri-ciriyaitu 1) rasional dalam penyusunan teori 2) tujuanjelas 3) tingkah laku untuk mencapai suatu pembelajaran dan 4) tempat belajar yang efisien agar tercapainya keberhasilan belajar. [14] model pembelajaran yang baik akan memliki ciriciri yang baik jugayaitu 1) intelektual-emosional siswa melalui kegiatan sikap, membuat, mengalami dan menganalisis 2) peserta didik ikut serta secara aktif dan kreatif 3) guru sebagai fasilitator, mediator, motivator dan koordinator 4) penggunaan alat, metode dan media pembelajaran. jadi disimpulkan bahwa pembelajaran itu baik ditentukan oleh empat aspek yaitu guru, peserta didik, perangkat pembelajaran dan media pembelajaran.

Problem Based Instruction adalah kegiatan pembelajaran dengan masalah dengan berpusat pada peserta didik dengan memberikan masalah sekitar siswa tersebut. Siswa melakukan kegiatan pemecahan masalah dan membuat siswa berpikir lebih kritis, mempresentasikan ide kreatif mereka sendiri, dan berkomunikasi dengan pelajaran secara lebih luas dan kritis, hasil belajar tidak hanya dapat meningkatkan pemahaman dalam suatu belajar dan penyerapan siswa tetapi juga meningkatkan keterampilan kraetifitas berfikir siswa [15]. Model pembelajaran berbasis masalah didasarkan pada teori pembelajaran konstruktivis. Model ini mulai belajar dengan menghadirkan masalah nyata yang solusinya membutuhkan kolaborasi antara siswa.

Pembelajaran yang nyata dan relevan merupakan pembelajaran berdasarkan masalah. Masalah tersebut bertujuan untuk menemukan konsep dari suatu pembelajaran supaya siswa tetap fokus dalam belajar, meningkatkan keaktifan atau motimasi siswa dalam belajar, dan meningkatkan semangat kepada siswa dalam belajar. Dari berbagai sumber yang telah diketahui dapat disimpulkan pembelajaran PBI adalah pembelajaran yang ada didunia nyata atau 
lingkungan yang dihubungkan kedalam proses pembelajaran siswa dengan materi pembelajaran sesuai dengan konsep dan ilmu pengetahuan.

Manfaat pembelajaran PBI yaitu dirancang untuk membantu pemecahan masalah, membantu keterampilan intelektual dan membantu mengembangkan kemampuan berpikir siswa. Pemecahan masalah merupakan manfaat khusus dari metode Deway. Dan pada model ini guru tidak menyajikan tugas pelajaran melainkan merumuskan tugas pelajaran, buku bukan objek dari pelajaran melainkan masalah yang ada disekitar merupakan objek dari pembelajaran ini.

Pembelajaran PBI berbasis keterampilan 4C ini adalah pengembangan pengetahuan dasar dan kompleks yang sangat cocok perkembangan siswa. Berdasarkan kerangka diatas, peneliti berharap pembelajaran menggunakan Problem Based Instruction berbasis keterampilan 4C dapat diterapkan dalam pembelajaran penerapan rangkaian elektronika.

\section{METODA}

Model pembelajaran Problem Based Instruction (PBI) berbasis keterampilan 4C menggunakan jenis penelitian eksperimen yang bersifat quasy eksperimen. Quasy eksperimen merupakan penelitian yang percobaannya mendekati sungguhan. Dalam penelitian ini pengaruh adanya perlakuan (treatmen) di analisis dengan uji beda yaitu kelompok mendapatkan perlakuan beda yaitu kelompok eksperimen model pembelajaran Problem Based Instruction (PBI) berbasis keterampilan 4C, kelompok kontrol dengan pembelajaran Konvensional (two group). Siswa kelas XI Jurusan TAV merupakan subjek dari penelitian ini pada semester ganjil yang sedang mengikuti mata pelajaran penerapan rangkaian elektronika dengan jumlah siswa di kelas XI TAV 1 berjumlah 21 siswa dan kelas XI TAV 2 berjumlah 22 siswa dengan jumlah total 43 siswa di SMK Negeri 3 Lubuklinggau.

Penelitian ini menggunakan kontrol eksperimen goup desain dengan mengunakan pre test dan post tes.

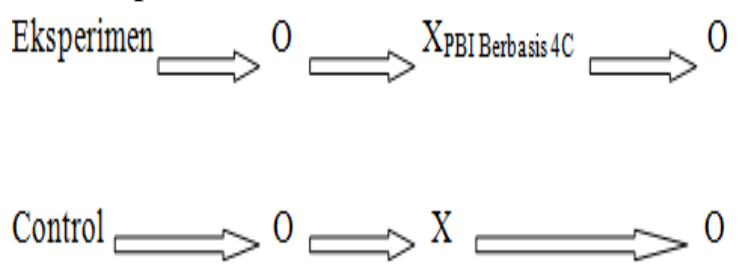

Gambar 3. Desain Penelitian
Berdasarkan gambar 3 kedua kelompok diberikan pretest sebelum percobaan dimulai kemudian kedua kelompok diberi perlakuan kelompok eksperimen menggunakan pembelajaran PBI berbasis 4C dan kelompok kontrol menggunakan model konvensional selama empat minggu.

Penelitian ini menggunakan dua variabel yaitu:

a. Variabel bebas $(\mathrm{X})=$ model pembelajaran Problem Based Instruction berbasis Keterampilan 4C

b. Variabel terikat $(\mathrm{Y})=$ Hasil Belajar

(Y) merupakan variabel terikat yang merupakan dari hasil belajar siswa yang akan menggunakan soal HOTS, (X) adalah variabel bebas yaitu menggunakan model pembelajaran Problem Based Instruction (PBI) berbasis keterampilan 4C dan konversional.

Instrumen untuk mengukur keefektifan model pembelajaran PBI berbasis keterampilan 4C berupa test. Test pretest dan posttest merupakan kegiatan yang akan mengetahui bagaimana hasil belajar pada mata pelajaran penerapan rangkaian elektronika. Tes ini menggunakan soal objektif dengan pilihan lima alternatif jawaban.

Postest kepada siswa merupakan cara pengambilan data menggunakan soal-soal yang dibuat untuk keperluan dan memeriksa hasil tes yang telah diberikan. validitas, realiblitas, taraf kesukaran dan daya beda butir soal merupakan kegiatan sebelum tes dilakukan.

a. Validitas

Perbandingan antara instrumen dengan materi merupakan proses dari pengujian validaritas instrumen uji coba terhadap materi yang diajarkan. Instrumen ini memiliki kisi-kisi yang dapat menjadi pedoman untuk menentukan soal-soal yang akan di tes. Untuk daya beda, reabilitas dan tingkat kesukaran merupakan uji kelayakan soal apakah soal bisa digunakan atau tidak.

\section{b. Tingkat kesukaran soal}

Kesukaran soal adalah bilangan yang dapat menunjukan apakah bilangan tersebut sukar atau tidak dalam soal.

\section{c. Daya Beda}

Suatu perbedaan antara peserta didik kemampuan tinggi dan peserta didik kemampuan rendah merupakan indikator dari daya beda soal. 
d. Reliabilitas

Untuk menunjukan Reliabilitas tes apakah tesebut sudah baik atau belum maka diperlukannya alat pengumpulan data yang dipercaya [16].

\section{HASIL DAN PEMBAHASAN}

A. Data hasil belajar kelas eksperimen dan kelas kontrol sebelum perlakuan (Pre Test)

Pada tahap ini, pretest dan posttest dilakukan untuk melakukan penilai pada kelompok eksperimen. Titik berat penilaian ini adalah penilaian pengetahuan siswa sebelum dan sesudah diberikan perlakuan tentang mata pelajaran rangkaian elektronika.

Tabel 1. Hasil Pretest kelas eksperimen

\begin{tabular}{|c|c|c|c|c|c|c|c|}
\hline & $\mathrm{N}$ & Min & Max & Sum & Mean & $\begin{array}{c}\text { Std. } \\
\text { Deviation }\end{array}$ & Variance \\
\hline $\begin{array}{l}\text { Pretest } \\
\text { Valid N } \\
\text { (listwise) }\end{array}$ & 22 & 60 & 96 & 1717 & 78.05 & 9.131 & 83.379 \\
\hline
\end{tabular}

Berdasarkan tabel 1 dapat dilihat Pretest kelompok Eksperimen berjumlah 22 orang, nilai rata-rata yaitu 78,05, data statistik sebesar 9.131 dan kuadrat selisih yaitu 83,379. Untuk nilai tertinggi bernilai 96 dan nilai terendah 60 dan jumlah skor keseluruhan sebesar 1771. Histogram dibuatberdasarkan perhitungan hasil analisis pretest, gambar histogram di lihat dari Gambar 4.

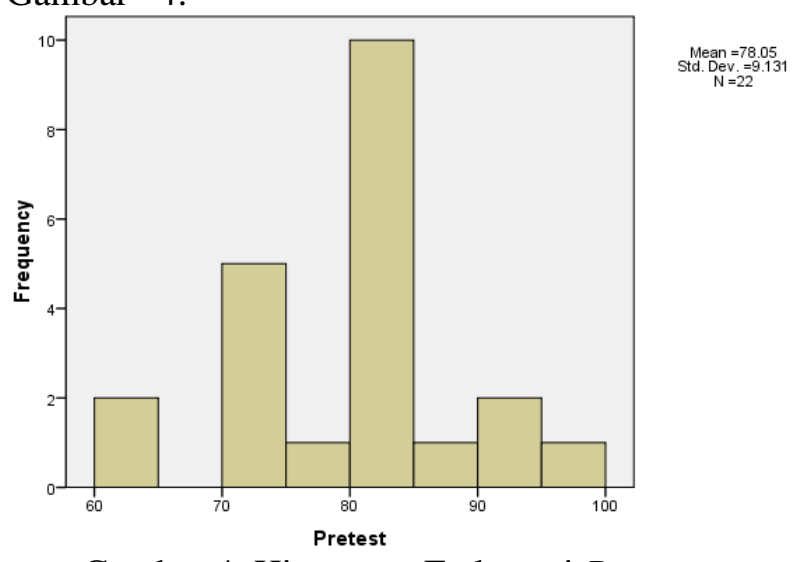

Gambar 4. Histogram Frekuensi Pretest Kelompok Eksperimen

Dari Gambar 4 dapat dilihat bahwa nilai pretest yang diperoleh paling tinggi bernilai 80 85 dan yang paling rendah yaitu 60 .
Tabel 2. Hasil Pretest Kelompok Kontrol

\begin{tabular}{|l|r|r|r|r|r|r|r|}
\hline & N & Min & Max & Sum & Mean & $\begin{array}{c}\text { Std. } \\
\text { Deviation }\end{array}$ & Variance \\
\hline Pretest & 21 & 50 & 98 & 1388 & 66.10 & 11.819 & 139.690 \\
$\begin{array}{l}\text { Valid N } \\
\text { (listwise) }\end{array}$ & 21 & & & & & & \\
\hline
\end{tabular}

Berdasarkan Tabel 2 Pretest kelompok kontrol dengan jumlah keseluruh data yaitu 21 orang, nilai rata-rata yaitu 66,10 . Ukuran sebaran sebesar 11,819 dan kuadrat selisih yaitu 139,960. Untuk nilai tertinggi bernilai 98 dan nilai terendah 50 dan jumlah nilai keseluruhan sebesar 1388. Grafik histogram dibuat berdasarkan perhitungan hasil analisis pretest, histogram di lihat dari Gambar 5.

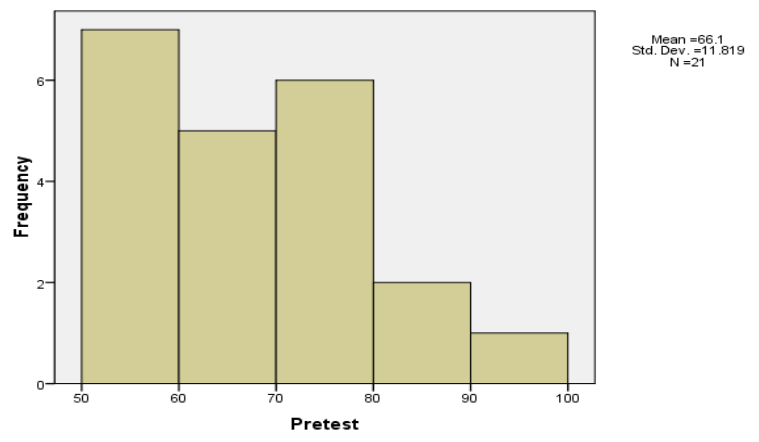

Gambar 5. Histogram Frekuensi Pretest Kelompok Kontrol

Berdasarkan Gambar 5 dapat di lihat nilai pretest pada kelas kontrol dengan nilai tertinggi 98 dan terendah 50.

B. Data hasil belajar setelah dilakukan perlakuan (Post Test)

Untuk melihat apakah adanya perubakan nilai siswa setelah diberikannya perlakuan dalam proses pembelajaran yaitu dengan menerapkan Problem Based Instruction berbasis 4C. Nilai dan Hasil analsis dari penilaian posttest dapat dilihat pada Tabel 3 dan Tabel 4.

Berdasarkan tabel 3 dapat dilihat Posttest kelompok Eksperimen dengan jumlah 22 orang, skor rata-rata yaitu 83,64, sebaran dari data statistik sebesar 10,031 dan kuadrat selisih 100,623 . Untuk nilai tertinggi bernilai 100 dan nilai terendah 60 dan jumlah skor keseluruhan sebesar 1840. Histogram dibuat berdasarkan perhitungan hasil analisis posttest, gambar histogram di lihat dari Gambar 6. 
Tabel 3. Hasil Posttest Kelompok Eksperimen
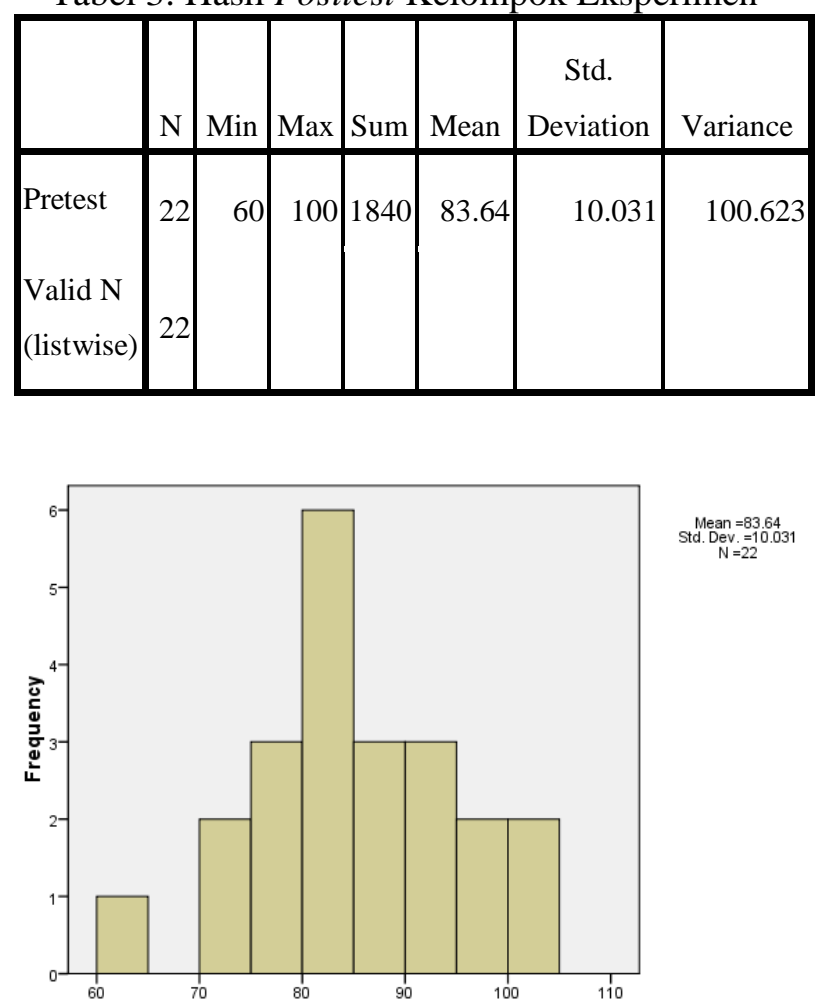

$\begin{aligned} \text { Mean } & =83.64 \\ \text { Std. Dev. } & =10.031 \\ N & =22\end{aligned}$

Gambar 6. Histogram Frekuensi Posttest

Kelompok Eksperimen

Berdasarkkan gambar 6 dapat dilihat nilai Posttest pada kelas eksperimen memiliki rata-rata 80-95 dan nilai tertinggi yaitu 100 .

Tabel 4. Hasil Posttest Kelompok Kontrol

\begin{tabular}{|c|c|c|c|c|c|c|c|}
\hline & $\mathrm{N}$ & Min & Max & Sum & Mean & $\begin{array}{c}\text { Std. } \\
\text { Deviation }\end{array}$ & Variance \\
\hline $\begin{array}{l}\text { Pretest } \\
\text { Valid N } \\
\text { (listwise) }\end{array}$ & $\begin{array}{l}21 \\
21\end{array}$ & 60 & 96 & 1713 & 81.57 & 9.796 & 95.957 \\
\hline
\end{tabular}

Berdasarkan tabel 4 dapat dilihat Posttest kelompok kontrol dengan jumlah 21 orang, skor rata-rata adalah 81,57, sebaran dari data yaitu 9,796 dan kuadrat selisih terhadap nilai rataratanya adalah 95,957. Untuk nilai tertinggi bernilai 96 dan nilai terendah 60 dan jumlah skor keseluruhan sebesar 1713. Histogram dibuat berdasarkan perhitungan hasil analisis posttest, gambar histogram di lihat dari Gambar 7.

Berdasarkan Gambar 7 dapat dilihat bahwa nilai paling tinggi yaitu 85 dan paling rendah 60 . Dari hasil pengujian secara keseluruhan pembelajaran menggunakan model Problem Based Instruction berbasis 4C terhadap hasil belajar penerapan rangkaian elektronika memberikan pengaruh kepada hasil belajar siswa. Sesuai kajian teori bahwa pembelajaran kooperatif digunakan sebagai tujuan supaya peserta didik dapat menghasilkan nilai yang lebih baik karena peserta didik dalam waktu mengerjakan tugas yang diberikan guru mereka berkerja sama dalam kelompoknya supaya dapat menemukan masalah sendiri tanpa bimbingan guru.

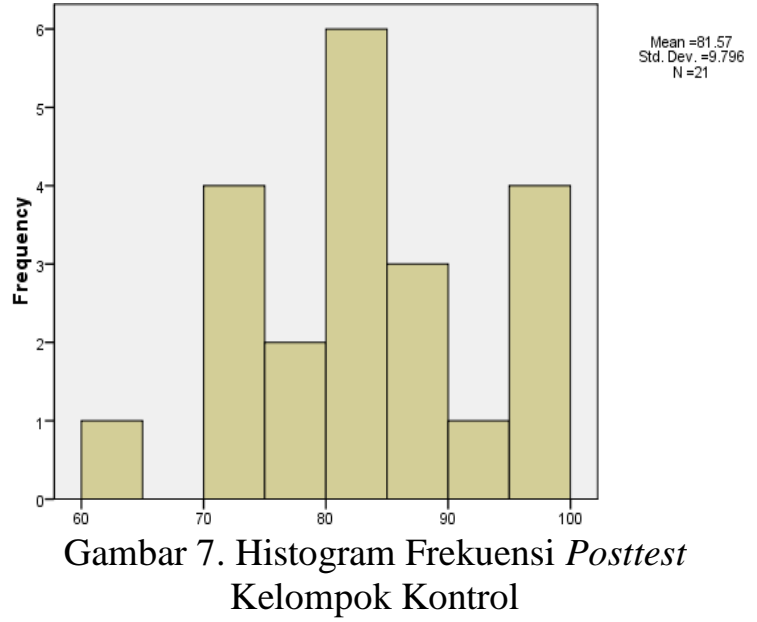

Peningkatan nilai rata-rata pada kelas kontrol memberikan dampak positif pada tingkat hasil belajar siswa. Peningkatan pada kelas eksperimen pre test dan post test yang menggunkan model pembelajaran Problem Based Instruction berbasis $4 \mathrm{C}$ lebih tinggi dari kelas kontrol pre test dan post test yang digunakan pembelajaran konvensional yang artinya bahwa setelah diberikan perlakuan dengan model pembelajaran Problem Based Instruction berbasis 4C memberikan dampak positif pada tingkat hasil belajar siswa.

Sejalan dengan penelitian yang dilakukan oleh [14] dengan kesimpulan bahwa penerapan Problem Based Instruction efektif meningkatkan hasil belajar siswa , serta dapat meningkatkan kreativitas siswa.

Perbedaan siswa kelompok eksperimen menggunakan model PBI berbasis 4C menjadikan peluang bagi mereka untuk lebih aktif dan kreatif dalam menyelesaikan masalah yang telah diberikan oleh guru sehingga mereka termotivasi untuk memecahan masalah dari tugasnya tersebut. Untuk kelas kontrol dengan model konvensional mereka hanya mendapatkan tugas yang sederhana.

Kelompok eksperimen mendapatkan tugas untuk menyelesaikan masalah yang berhubungan dengan kompetensi dasar dan sesuai dengan 
keadaan nyata. Mekanisme dan prosedur model pembelajaran disusun sesuai dengan bobot pembelajaran. Spesifikasi mata pelajaran didapat dari capaian pembelajaran yang dirumuskan dalam dokumen kurikulum. Rumusan tersebut disesuaikan dengan Problem Based Instruction. Dalam Problem Based Instruction pengaturan kelas pada kegiatan ekpolarasi adalah suatu pembelajaran yang menciptakan suasana supaya peserta didik dapat menyalurkan aktivitas fisik dengan memanfaatkan panca indra dengan berbagai cara, media dan pengalaman dalam menentukan ide, konsep, gagasan serta prinsip sesuai dengan kompetensi dasar.

\section{KESIMPULAN}

Berdasarkan hasil dan analisis data serta pengujian hipotesis, maka dapat disimpulkan bahwa :Hasil belajar siswa dalam mata pelajaran Rangkaian Elektronika melalui penggunaan Problem Based Instruction (PBI) berbasis keterampilan 4C lebih baik dibandingkan hasil belajar menggunakan pembelajaran konvensional pada siswa SMK Negeri 3 Lubuklinggau jurusan TAV dikelas XI.Nilai posttest pada kelompok eksperimen, terdapat 13,6\% siswa yang belum kompeten dan 86,3\% siswa yang kompeten, sedangkan nilai posttest pada kelompok kontrol terdapat 23,8\% siswa yang belum kompeten dan $76,2 \%$ siswa yang kompeten.Berdasarkan uji hipotesis, terelihat bahwa nilai $t_{\text {hitung }}$ lebih besar dari $t_{\text {tabel}}$, hal ini berarti bahwa pembelajaran dengan menggunakan Problem Based Instruction lebih efektif dalam meningkatkan hasil belajar siswa dibandingkan dengan metode konvensional.

\section{DAFTAR PUSTAKA}

K. Visal,“Industrial revolution”, 58-65, 2017, [Online].

Tersedia: https://www.britannnica.com/event/IndustrialRevolusi [Diakses: 25 Oktober 2019].

[2] E. C. Moraes and H. A. Lepikson, "Industry 4.0 and its impacts on society," In Proceedings of the International Conference on Industrial Engineering and Operations Management (pp. 25-26), 2017.

[3] et all Roblek, V, "A complex view of industry 4.0," Sage Open, 6(2), 2158244016653987, 2016.

[4] E. Prihandi, "Pengembangan keterampilan 4c melalui metode poster comment pada mata pelajaran pai dan budi pekerti (Penelitian di
SMA Negeri 26 Bandung)," Jurnal Pendidikan Islam Rabbani, vol.2, no. 1, 2018.

[5] Z. Zulhiyah, "Pengaruh Model Pembelajaran Creative Problem Solving Terhadap Keterampilan Berpikir Kreatif dan Komunikasi Peserta Didik Dalam Pembelajaran IPS," Bandung: Pascasarjana Universitas Pendidikan Indonesia, 2013.

[6] S. Sajidan, and Afandi, A. Afandi, "Pengembangan model pembelajaran ipa untuk memberdayakanketerampilan berpikir tingkat tinggi," In Prosiding SNPS (Seminar Nasional Pendidikan Sains)., pp. 15-27, 2017.

[7] P. Griffin and E. Care, Assessment and Teaching of 21st Century Skills. Springer: Methods and approach, 2014.

[8] Chambers, J. H. Chambers, The Achievement of Education: An Examination of Key Concepts In Educational Practice. Harper Collins Publishers, 1983.

[9] Sagala, S. Sagala, Konsep dan makna pembelajaran. Bandung: Alfabeta, 2010.

[10] R. Ismawati and N. Wijayati, "Pengaruh Model Pembelajaran Inkuiri Berstrategi REACT terhadap Hasil Belajar Kimia Siswa SMA Kelas XI," Jurnal Inovasi Pendidikan Kimia, vol. 7, no. 1. 2013

[11] Y. A. Damai and Y. I. Basri, "Pengaruh penerapan media pembelajaran trainer ic 555 pada mata kuliah listrik dan elektronika terhadap peningkatan hasil belajar mahasiswa teknik otomotif," Jurnal Inovasi Vokasional dan Teknologi, vol. 2, no. 19, 2019.

[12] I. B. A. Trianto, Mendesain Model Pembelajaran Inovatif, Progresif, Dan Kontekstual, Jakarta: Prenada media Group, 2017

[13] S. Agus, "Cooperative Learning Teori Dan Aplikasi Paike, Yogyakarta: Pustaka Pelajar, 2009.

[14] M. Fathurrohman, Model-Model Pembelajaran Inovatif, Yogyakarta: Ar-Ruzz Media, 2015.

[15] Sinambela, P. N. Sinambela, "Faktor-faktor penentu keefektifan pembelajaran dalam model pembelajaran berdasarkan masalah (problem based instruction)," GenerAsi Kampus, vol. I no.2, 2014.

[16] A. Suharsimi, Dasar-Dasar Evaluasi Pendidikan, Jakarta: Bumi Aksara, 2019.

\section{Biodata Penulis}

Ayu Alam Pertiwi, Lahir di Lubuklinggau tanggal 14 Oktober 1991. Sarjana Teknik Elektro Industri dari Universitas Negeri Padang. Mahasiswa Magister Pendidikan Teknologi Kejuruan Program Studi Pendidikan Teknik Elektro Universitas Negeri Padang dan bekerja sebagai guru SMK Negeri 3 Lubuklinggau. 
Fahmi Rizal, Lahir di Kamang Mudik tanggal 4 Desember 1959. Beliau lulus Sarjana (S1) pada tahun 1983 di Jurusan Teknik Bagunan IKIP Padang, Magister Pendidikan (S2) di IKIP Jakarta pada tahun 1992, Magister Teknik (S2) UGM Yogyakarta pada tahun 2000, dan Doktor (S3) dan Bidang Ilmu Pendidikan di Universitas Negeri Jakarta pada tahun 2007. 